\title{
Turtles of the Northern Aravalli Ridge (Kamla Nehru Ridge) and the First Report of the Indian Black Turtle, Melanochelys trijuga (Schweigger 1812), from the State of Delhi
}

\author{
Gaurav Barhadiya ${ }^{1}$, Faiyaz A. Khudsar ${ }^{2}$, and Dinesh Albertson ${ }^{2}$
}

${ }^{1}$ Department of Environmental Studies, University of Delhi, New Delhi, Delhi-110007, India (Gaurav7wild7@gmail.com) ${ }^{2}$ Centre for Environmental Management of Degraded Ecosystems (CEMDE), University of Delhi, New Delhi, Delhi-110007, India

$\mathrm{T}$ urtles include many species threatened with extinction in the wild if effective conservation plans are not implemented (Stanford et al. 2018). Turtles (Order Testudines) are mostly aquatic (i.e., they live in both freshwater and marine habitats) and some (e.g., tortoises) have adapted to terrestrial habitats (Sharma 1998). India is home to 29 chelonian species (Basumatary and Sharma 2013).

The Aravalli Hill Ranges are among the oldest mountain ranges in the world. The spur that extends into the state of Delhi is known as the Delhi Ridge, which is further divided into the Southern Ridge, South-central Ridge, Central or New Delhi Ridge, and Northern, Old Delhi, or Kamla Nehru Ridge (Kalpavriksh 1991). We have been conducting surveys to document the biodiversity of the Kamla Nehru Ridge (hereafter KNR), an area of about 122 ha with numerous bodies of water in the North Delhi District $\left(28^{\circ} 40^{\prime} 50^{\prime \prime} \mathrm{N}\right.$, 077¹3'01"E) (Fig. 1).

A recent biodiversity assessment of the KNR by Barhadiya (2016) recorded 50 native and 15 exotic species of trees, 80 species of birds, and several species of amphibians, reptiles,

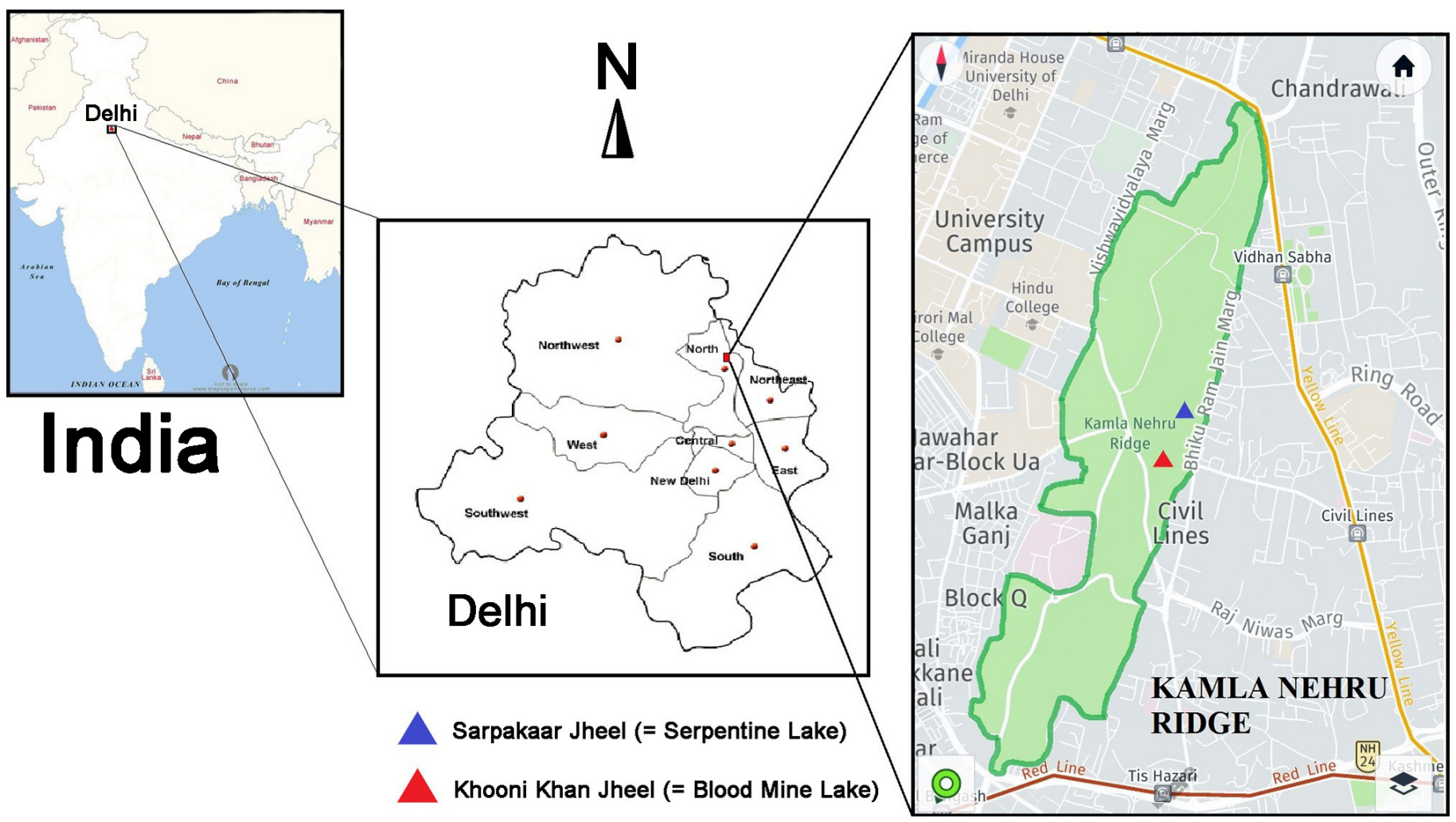

Fig. 1. Map showing location of Kamla Nehru Ridge in Delhi, India. 

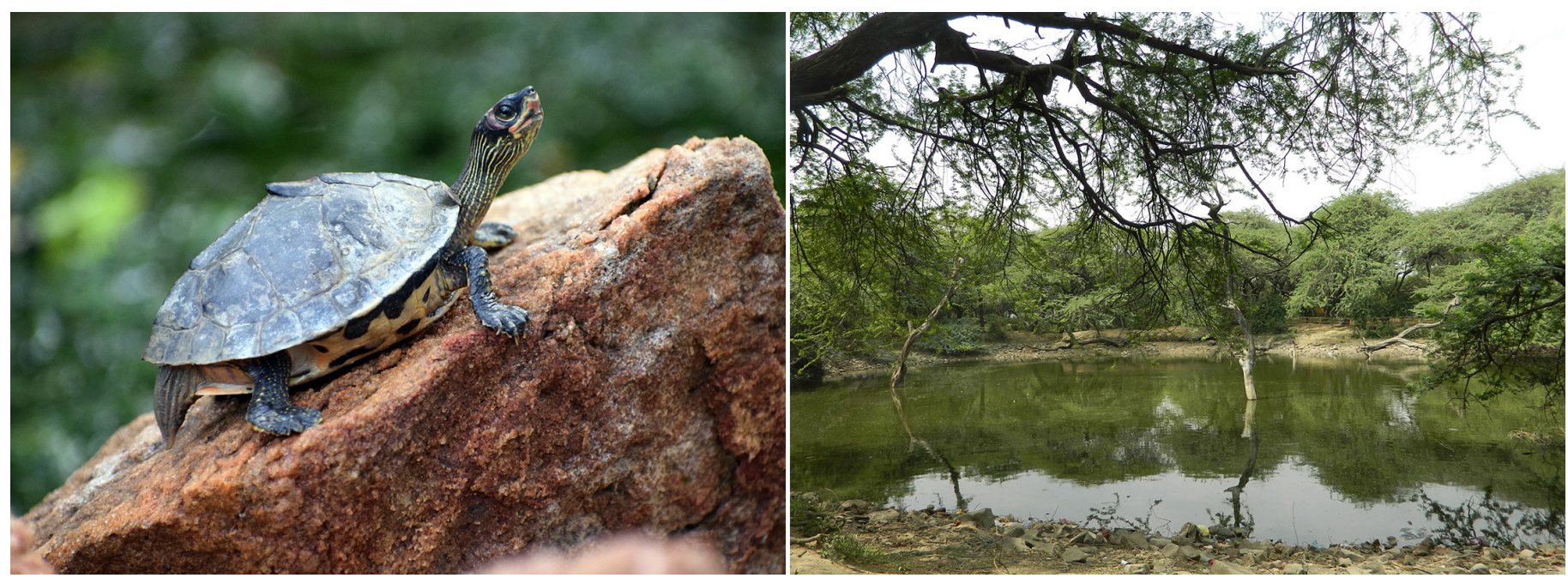

Fig. 2. A juvenile Indian Roofed Turtle (Pangshura tecta) (left) from Sarpakaar Jheel (= Serpentine Lake) (right) on the Kamla Nehru Ridge in Delhi, India. Photographs by Gaurav Barhadiya.

and mammals. Intensive searches for turtles from September 2016 through January 2019 involved daily surveys of all bodies of water using binoculars and field scopes, interviews with the local population and other people who are closely associated with the ridge, and a thorough review of the literature documenting the past and present status and distribution of
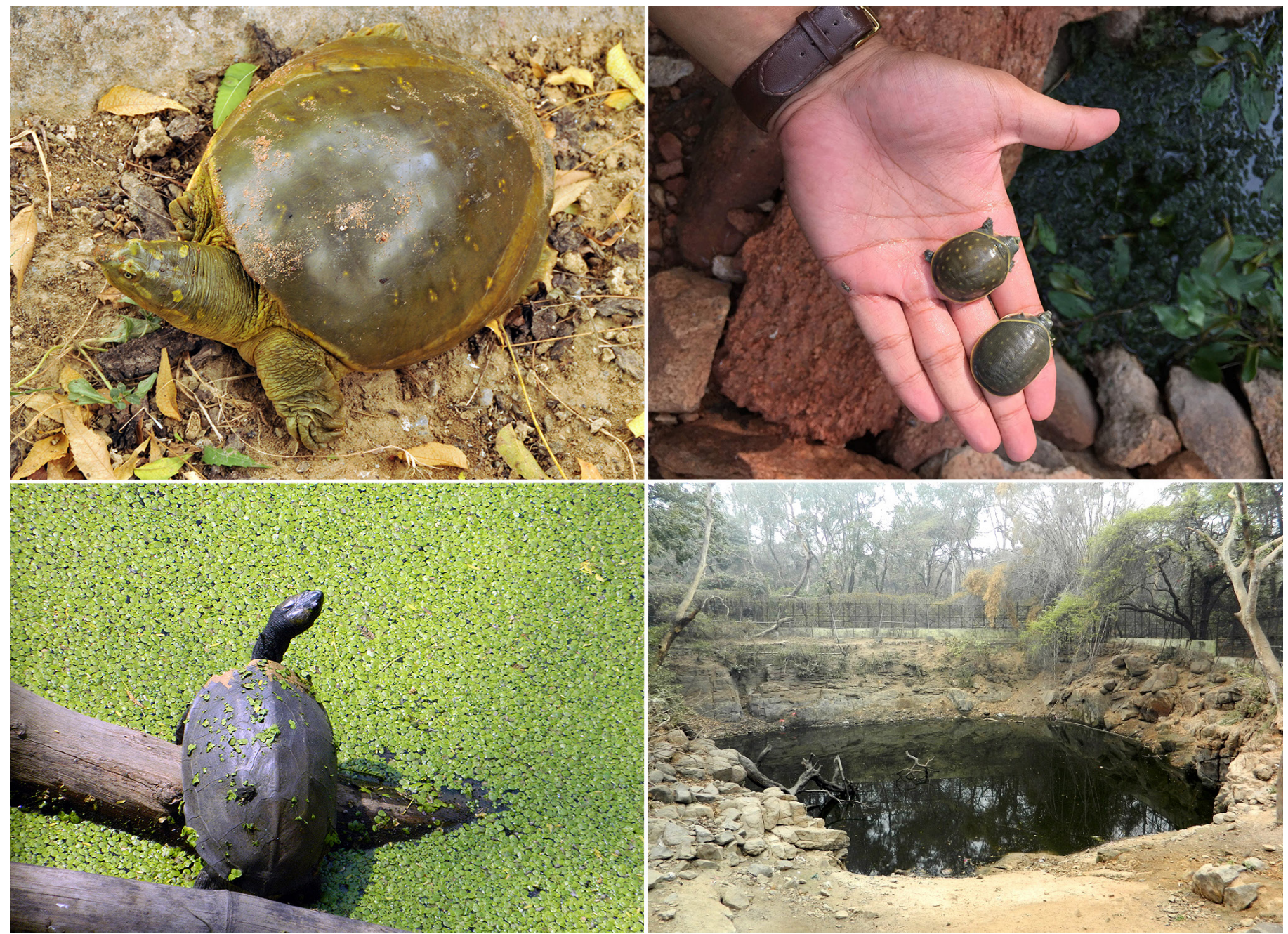

Fig. 3. Adult (upper left) and hatchling (upper right) Indian Flap-shelled Turtles (Lissemys punctata) and an Indian Black Turtle (Melanochelys trijuga) (lower left) from Khooni Khan Jheel (= Blood Mine Lake) (lower right) on the Kamla Nehru Ridge in Delhi, India. Photographs by Gaurav Barhadiya. 
flora and fauna in the area. To avoid disturbing the few turtles encountered, we did not attempt to collect specimens.

We found eleven individual turtles at KNR, a juvenile Indian Roofed Turtle, Pangshura tecta (Gray 1830) from Sarpakaar Jheel (= Serpentine Lake) (Fig. 2), and five adult and three hatchling Indian Flap-shelled Turtles, Lissemys punctata (Lacépède 1788) and two adult Indian Black Turtles, Melanochelys trijuga (Schweigger 1812) from Khooni Khan Jheel (= Blood Mine Lake) (Fig. 3). The Indian Black Turtles are reported herein for the first time from the state of Delhi. Husain (1997) listed only two species of turtles in Delhi, L. punctata and the Ganges Soft-shelled Turtle, Nilssonia gangetica (Cuvier 1825) (as Aspideretes gangeticus), and Barhadiya and Khudsar (2019) recorded the presence of P. tecta in the state.

A number of Asian species of turtles are on the brink of extinction (e.g., Stanford et al. 2018). Although Melanochelys trijuga is listed currently as Near Threatened on the IUCN Red List (Asian Turtle Trade Working Group 2000b) and both Lissemys punctata and Pangshura tecta as being of Least Concern (Asian Turtle Trade Working Group 2000a, 2000c), those accounts are in need of updating. Threats are ongoing (e.g., Ahmed et al. 2005, 2009; Krishnakumar et al. 2009; Ahmed and Das 2010) and all three species almost certainly warrant listing in a more threatened category.

\section{Acknowledgements}

We are extremely thankful to Prof. C.R. Babu, the principal investigator of the Biodiversity Parks Programme for his continuous support, encouragement, and guidance. The authors also thank Dr. Debanik Mukherjee, Field Biologist, Aravalli Biodiversity Park, for confirming the identities of the turtles reported in this paper. Finally, we thank Dr. A.K Singh, Scientist-in-Charge, and Mr. Harmeek Singh and Bhuvan Chopra (Supervisors) of Kamla Nehru Ridge, CEMDE, for help and support.

\section{Literature Cited}

Ahmed, M.F. and A. Das. 2010. Tortoises and Turtles of Northeast India: Saving them from Extinction! Survey, Assessment of Present Status and Conservation of Tortoises and Freshwater Turtles in Northeast India. Technical Report, Aaranyak, Guwahati, India.

Ahmed, M.F., A. Das, B.P. Lahkar, R.N. Sharma, and N.K. Vasu. 2005. Herpetofauna of Kaziranga National Park: Inventory, Natural History and Conservation Status with Observations on Impact of Grassland Burning. Aaranyak, Guwahati, India.

Ahmed, M.F., A. Das, and S.K. Dutta. 2009. Amphibians and Reptiles of Northeast India - A Photographic Guide. Aaranyak, Guwahati, India.

Asian Turtle Trade Working Group. 2000a. Lissemys punctate (errata version published in 2016). The IUCN Red List of Threatened Species 2000: e.T46579A97399871.

Asian Turtle Trade Working Group. 2000b. Melanochelys trijuga (errata version published in 2016). The IUCN Red List of Threatened Species 2000: e.T13039A97373591.

Asian Turtle Trade Working Group. 2000c. Pangshura tecta (errata version published in 2016). The IUCN Red List of Threatened Species 2000: e.T46370A97374974.

Barhadiya, G. 2016. Biodiversity Assessment of Kamla Nehru Ridge. Unpublished M.Sc. Dissertation, Department of Environmental Studies, University of Delhi, New Delhi, Delhi, India.

Barhadiya, G. and F.A. Khudsar. 2019. First record of an Indian Roofed Turtle, Pangshura tecta (Gray 1830), from Delhi, India. Reptiles \& Amphibians 26: 42.

Basumatary, R. and D.K. Sharma. 2013. The turtle fauna of Kaziranga National Park, Assam, India with note on natural history and conservation status. Herpetology Notes 6: 59-72.

Husain, A. 1997. Reptilia, pp. 665-698. In: J.R.B. Alfred (ed.), Fauna of Delhi. Zoological Survey of India, Dehra Dun, India.

Kalpavriksh. 1991. The Delhi Ridge Forest: Decline and Conservation. Kalpavriksh, New Delhi, Delhi, India.

Krishnakumar, K., R. Raghavan, and B. Pereira. 2009. Protected on paper, hunted in wetlands: Exploitation and trade of freshwater turtles (Melanochelys trijuga coronata and Lissemys punctata punctata) in Punnamada, Kerala, India. Tropical Conservation Science 2: 363-373.

Sharma, R.C. 1998. Fauna of India and Adjacent Countries. Reptilia Volume I (Testudines and Crocodilians). Zoological Survey of India, Kolkata, India.

Stanford, C.B., A.G.J. Rhodin, P.P. van Dijk, B.D. Horne, T. Blanck, E.V. Goode, R. Hudson, R.A. Mittermeier, A. Currylow, C. Eisemberg, M. Frankel, A. Georges, P.M. Gibbons, J.O. Juvik, G. Kuchling, L. Luiselli, H. Shi, S. Singh, and A. Walde (eds.). 2018. Turtles in Trouble: The World's 25+ Most Endangered Tortoises and Freshwater Turtles - 2018. Turtle Conservation Coalition (IUCN SSC Tortoise and Freshwater Turtle Specialist Group, Turtle Conservancy, Turtle Survival Alliance, Turtle Conservation Fund, Conservation International, Chelonian Research Foundation, Wildlife Conservation Society, and Global Wildlife Conservation), Ojai, California. 